> Gi respons på artikler gjennom artiklenes kommentarfelt på tidsskriftet.no.

Innleggene publiseres fortløpende på Tidsskriftets nettside og et utvalg

av innleggene publiseres også i papirutgaven i spalten «Brev til redaktøren».

Redaksjonen forbeholder seg retten til å foreta redaksjonelle endringer.

Forfattere av vitenskapelige artikler har tilsvarsrett, jf. Vancouver-gruppens regler.

\section{Re: Å stirre døden i hvitøyet}

Takk til Materstvedt for den interessante og personlige fortellingen om «å stirre døden i hvitøyet» i Tidsskriftet nr. 6/2015 (1), og spesielt for hans rungende «nei» til å «akseptere døden». Jeg kjenner igjen denne motviljen blant foreldre til barn med trisomi 18, meg selv inkludert. Hvorfor i all verden skal vi «akseptere døden» på vegne av våre trisomibarn? Hvorfor skal vi ta til takke med et palliativt fokus, når det vi ønsker for våre barn er mulighet til å leve? For våre barn blir dessuten presset om å «akseptere døden» og det lindrende fokus med manglende vilje til behandling, til en selvoppfyllende profeti.

\section{Siri Fuglem Berg}

sirifberg@gmail.com

Siri Fuglem Berg (f. 1969) er forsker ved Sykehuset Innlandet Helseforetak, Gjøvik.

Ingen oppgitte interessekonflikter.

\section{Litteratur}

1. Materstvedt LJ. Å stirre døden i hvitøyet. Tidsskr Nor Legeforen 2015; 135 : 565-6.

\section{Re: Pasienten i sentrum}

«Bent Høie ønskjer å skape pasienten si helseteneste» kan vi lese $i$ et intervju med helseministeren i Tidsskriftet nr. 6/2015 (1). Pasientens helsetjeneste bør først og fremst bli bedre, ikke dårligere. Pasientens helsetjeneste må også, i tråd med spesialisthelsetjenesteloven, sikre alle pasienter et likeverdig tilbud, uansett hvor de bor eller oppholder seg. Det er urovekkende at statsråden gir uttrykk for at det er banalt at pasientene ønsker nærhet til spesialisthelsetjenesten, samtidig som han prøver å gi inntrykk av at han vil overføre mer makt til den enkelte pasienten. Den enkelte pasienten har et basalt ønske om å overleve. Det hjelper fint lite hvor god kvalitet det er på det sentraliserte spesialistsykehuset, hvis pasienten allerede er død ved ankomst.

For de mange pasientene rundt omkring i landet som allerede har mistet, eller står i fare for å miste, lokalsykehus og -avdelinger er det derfor ikke betryggende når statsråden sier at den medisinske utviklingen tilsier et spesialisert og sentralisert kirurgitilbud. Det er riktignok mye som kan sentraliseres, og planlagt behandling kan strengt tatt foregå hvor som helst i landet, eller for den del i utlandet.

Men det er ikke ved planlagt behandling avstanden til sykehuset er et problem, men ved akuttsituasjoner. Likeverd og muligheter for alle handler ikke først og fremst om hvor lang tid det tar å få en hofteoperasjon, men om hvor lang tid det tar å få behandling for slag, hjerteinfarkt, hjertestans, pustestans og traumer. Prehospitale tjenester kan aldri erstatte akuttmottaket, og helikopter kan aldri erstatte bil og båt. Et sentralisert spesialistsykehus kan heller ikke veie opp for et akuttmottak uten kirurg på vakt.

Dersom statsråden mener alvor med at makt skal flyttes til pasienten, synes jeg det er på tide å begynne å lytte til de frustrerte pasient- og pårørendegruppene rundt omkring i landet som kjemper for å beholde de sykehusene og avdelingene de har og har hatt.

Hvis du gir pasienten makt og lytter til hva pasienten ønsker, vil pasientens helsetjeneste først og fremst bestå av nærhet til barne- avdeling, fødeavdeling og akuttmottak med indremedisin og kirurgi, samt støttefunksjoner.

For å opprettholde pasientens helsetjeneste som et likeverdig spesialisthelsetjenestetilbud uavhengig av bo- eller oppholdssted, er sentralisering det motsatte av hva pasienten vil bruke sin makt til å oppnå. For å opprettholde pasientens helsetjeneste er det tvert imot nødvendig å desentralisere spesialisthelsetjenesten, slik at det er mulig å bygge opp og holde på kompetanse lokalt. Spesialister vil gjerne søke seg til små lokalsykehus med spisskompetanse, så lenge de ikke opplever de små sykehusene som nedleggingstruet. Jeg mener mangel på spesialister i lokalsykehusene først og fremst er et politikerskapt problem. Med politisk vilje til å beholde og forsterke et desentralisert spesialisthelsetjenestetilbud i stedet for å rasere det tilbudet som er bygd opp over tid, vil spesialistene på nytt søke tilbake til de mindre lokalsykehusene, fordi de igjen vil være attraktive og faglig interessante kompetansearbeidsplasser.

\section{Stig Ohrvik \\ stigohrvik@gmail.com}

Stig Anders Ohrvik (f. 1970) er daglig leder.

Oppgitte interessekonflikter: Stiller til valg for Nordmørslista ved fylkestingsvalget 2015 i Møre og Romsdal.

\section{Litteratur}

1. Homlong L. Pasienten i sentrum. Tidsskr Nor Legeforen 2015; 135: 530-2.

\section{Re: Ny og bedre medisin mot hjertesvikt}

I Tidsskriftet nr. 3/2015 omtales en randomisert studie av et nytt legemiddel mot hjertesvikt (1). Studien er finansiert av Novartis og publisert i New England Journal of Medicine (2). Legemidlet er et kombinasjonspreparat (LCZ696) av angiotensin-2-reseptorantagonisten valsartan og en hemmer av enzymet neprilysin kalt sacubitril (AHU-377).

En lignende hemmer av både neprilysin og angiotensinkonverterende enzym (ACE), omapatrilat, ble trukket tilbake helt eller delvis pga. høy forekomst av alvorlig angioødem. Mekanismen var redusert nedbrytning av bradykinin (3). Angioødem pga. plasmalekkasje, men også mye av den ønskede blodtrykksenkende effekten, skyldes at denne gruppen legemidler bremser nedbrytning av bradykinin. Angioødem under behandling med ACE-hemmer har vært kjent lenge, men overrasker mange fortsatt. Kanskje fordi angioødemet kan komme etter flere års behandling (4).

Hemmes ett eller flere av de bradykininnedbrytende enzymer medikamentelt, vil bradykininnivået være prisgitt funksjonen i de gjenværende enzymene (5). Pga. individuelle polymorfier og mutasjoner i genene som koder for disse bradykininnedbrytende enzymene, kan funksjonen være lav hos noen. Det kan forklare hvorfor bare noen pasienter får bradykininmediert angioødem under enzymhemming (6). En ny gruppe antidiabetika hemmer dipeptidylpeptidase-4, og en samtidig forordning av ACE-hemmer er vist å øke risikoen for alvorlig angioødem (7). En rekke tilfeller er rapportert allerede (5).

Også rene angiotensinreseptorantagonister kan gi angioødem $(8,9)$, men sjeldnere enn ACE-hemmere. Av denne grunn er det ventet at også det nye kombinasjonspreparatet LCZ696 vil kunne 